\title{
Attitudes and Perspectives of Saudi Female Medical Students towards Online EFL Education under COVID-19 Circumstances
}

\author{
Seham Elashhab \\ English Language Center \\ Umm AL-Qura University, Makkah, Saudi Arabia \\ Email: saelashhab@uqu.edu.sa
}

Received: $10 / 1 / 2021$

Accepted: 12/17/2021

Published: $1 / 24 / 2022$

\begin{abstract}
COVID-19 pandemic has caused many educational institutions across the globe to lockdown. Employing online educational models was the best solution to prevent the spread of the virus. This study depicts the attitudes and perspectives of Saudi female medical students towards online English language learning during the pandemic lockdown. The aim is to identify the challenges of online learning to understand the students' learning experiences and suggest practical solutions. The two main questions are: How do virtual education approaches influence students' educational behavior, and what are the students' perspectives towards virtual education amid the pandemic? After two semesters of solely distance education, a questionnaire was conducted to scrutinize students' perceptions of online learning using Zoom, Cisco WebEx, and Blackboard platforms. Fifty-seven students enrolled in their first-year medical program in the 2020/2021 academic year participated in this study. "Quantitative as well as qualitative" methods were used. Results indicate that an average of $63.52 \%$ of students preferred distance education over onsite. However, $69.5 \%$ of students encountered technical difficulties. On the other hand, online education was more enjoyable than onsite education for $45.6 \%$ versus $19.3 \%$ who did not enjoy it. Further, $50.8 \%$ of students were more active during online classes, and $59.6 \%$ perceived online education as an efficient teaching method to expand their knowledge, skills, and social competence. The data reflects that the general attitudes towards distance education were positive. Furthermore, the findings demonstrate a need for special attention to providing further technical support for students who experience technical difficulties.
\end{abstract}

Keywords: attitudes, COVID-19 Pandemic, EFL onsite instruction, online education, perspectives, Saudi female students

Cite as: Elashhab, S. (2022). Attitudes and Perspectives of Saudi Female Medical Students towards Online EFL Education under COVID-19 Circumstances. Arab World English Journal (AWEJ) $2^{\text {nd }}$ Special Issue on Covid 19 Challenges (2)

DOI: https://dx.doi.org/10.24093/awej/covid2.7 


\section{Introduction}

As witnessed, the COVID-19 pandemic has obstructed educational processes in various institutions worldwide. It led universities to shut their campus doors for extended periods in most countries, including Saudi Arabia, where the present study takes place. Regular classes were put on hold to assure the safety of students, instructors, and others involved in the field. All workplace cultural and educational activities were modified around social distancing complying with the Saudi government's mandatory national health and safety measures. This sudden closure led institutions to resort to online education; such was quickly adopted and validated as an efficient alternative and a modification in the educational systems allowing study programs to presume their activities.

Consequently, e-education (electronic education) became a fundamental approach for delivering curricular content during the COVID-19 pandemic. The use of technology in education is not new to many study programs. It has been around for some time, but most universities usually perform in-person or onsite courses. Therefore, it was not common to integrate new educational approaches presented by electronic instruction and educational applications and programs. Zhao et al. (2020) state that universities find current technology that empowers online education provides working solutions and approaches for teaching students while reducing the negative effect of schools' closure.

The shift of the educational approaches from onsite to online education reveals various perceptions of students and other involved parties. Online educational tools come with advantages and challenges. It may affect learners' goal achievement (Allo, 2020). Students certainly have their perspectives, attitudes, and perceptions towards distance learning during the pandemic. That plays an essential role in appropriating program content and providing inputs and feedback for instructors and institutions to run their online programs continue administering them optimally and successfully.

With this background, the purpose of the present study is to find out both the positive and the negative aspects of distance education from the perspectives of university students enrolled in online EFL courses during the pandemic. At this point, it is essential to scrutinize students' opinions and viewpoints regarding this new virtual approach to teaching and learning. There would be some interesting significant points to explore. This study investigates the attitudes and perspectives of virtual learning from a sample of specific participants (Saudi female first-year medical students learning English online) that had not been examined before. Therefore, this study aims to answer the following research questions:

1. How do virtual education methods influence students' moods and education behavior?

2. What are the students' perspectives towards virtual education amid the COVID-19 pandemic?

3. Does distance education affect EFL learners' class participation?

4. To what extent was online education enjoyable to language learners?

\section{Research Objectives}

- Determine the Saudi female medical student's perspectives and attitudes towards online language learning during the Covid-19 pandemic. 
Arab World English Journal (AWEJ) 2nd Special Issue on Covid 19 Challenges January 2022

Attitudes and Perspectives of Saudi Female Medical Students towards Online EFL

Elashhab

- Determine the advantages and disadvantages of e-education from the students' viewpoints.

- Determine the students' classroom participation during online classes compared to conventional classes.

- Determine the challenges students may face during online learning.

- Determine the impact of e-education on the students' feelings during online classes.

\section{Literature Review}

\section{Online Courses Versus Onsite courses}

Distance education is the umbrella term often used to refer to ways of teaching and learning that occur across distance and not necessarily in a physically shared space as a classroom. On the other hand, online learning is simply the education that takes place over the internet. Therefore, in this paper, the terms: online learning, distance education, virtual classes, e-education, online instruction, and virtual education are used alternatively to refer to the education of students who are not physically present at a school. This work relates to the body of research on language learning attitudes (Amir et al., 2020; Bączek, Zagańczyk-Bączek, Szpringer, Jaroszyński, Wożakowska-Kapłon, 2021; Abbasi, Ayoob, Malik and Memon, 2020; Ali, 2020). It contributes to the existing literature by examining female medical students' attitudes towards their online language learning setting in Saudi Arabia to enlighten this research area that is not investigated yet. Many researchers examined this topic in similar contexts. For instance, in Poland, Bączek et al. (2021) investigated medical students' perception of online learning during the COVID-19 pandemic. They stated that "e-learning was considered less effective than face-to-face learning in increasing language skills and social competence." Furthermore, their students admitted that they were less active during online classes compared to the traditional classroom setting.

Nevertheless, most of them (73\% of the participants) considered E-learning enjoyable. Abbasi et al. (2020) explored students' perceptions regarding aspects of e-education during COVID-19 at a private medical college in Pakistan. Their results showed that $77 \%$ of their participants had negative perceptions towards e-learning and did not prefer online over onsite classes during the lockdown situation. Another study by Amir et al. (2020) also examined students' classroom perspectives compared to distance education during the COVID-19 pandemic in an Indonesian undergraduate dental study program. They found that students accepted and adapted to the new blended learning model that combined classroom and distance learning. Further, Bozavli (2021) studied EFL students at Atatürk University. His findings showed that "students believe that they can't learn a foreign language without going to school. Additionally, the findings indicated that their digital literacy skills are insufficient in distance teaching, and students show low motivation in learning" (p.3). In Malaysia and Indonesia, Chooi-Seong, Kah-Mun, and Chee-Seong (2021) also investigated "the impact of online learning on students' anxiety, academic achievement, and satisfaction on the effectiveness of online learning during this pandemic period" (p.368). They reported that "participants' academic achievement indicates that they were satisfied with the online learning experience" (p.367). Therefore, the present paper adds to recent studies that examine students' perspectives of online language learning during the Covid-19 pandemic in different countries. This study intends to fill the literary gap by shedding light on Saudi female medical students' attitudes towards online language learning in a Saudi university. 
Typically, in virtual settings, instructors and the learners are not physically present in the same space but rather separated in different venues and communicated via several electronic platforms. The notion of distance education is proved functional at this specific challenging time of the pandemic (Ali, 2020). With the dominance of e-education, researchers, educators, students, and others indulged in the process may ask if online teaching could efficiently replace conventional onsite activities in terms of teaching quality and educational outcomes? Ali (2020) argued that virtual education could only meet a few educational requirements as teaching is a vast unrestricted process. In other words, virtual education does not equip learners with restricted course outlines and assessment tools. However, it provides a motivating and encouraging learning environment, leading to self-directed learning. It also creates a constructive competitive environment and provides opportunities for growth and development. According to Ali (2020), such are achievable through typical conventional onsite instruction.

According to Aristovnik, Kerži cc, Ravšelj, Tomaževi`c, and Umek (2020), online instruction is more than simply uploading educational materials on the various electronic teaching platforms and applications. Instructors need to organize their content and apply adequate educational approaches that fit the new instructional setting and style. In addition, they account for learners' feelings of being distant and isolated during their course. On this issue, Bączek et al. (2021) point out that securing knowledgeable, skillful instructors and "Information and Communication Technology" (ICT) equipment is vital to the success of the process and to assure adequate elearning experience for students. Such is similarly recommended in other studies highlighted by the authors (e.g., Keskin, and Yurdugül, 2020; Angdhiri, 2020) of several studies in nations where distance education has not been widely spread yet before the COVID-19 pandemic.

Furthermore, various online educational challenges have been reported learner-teacher communication, student-student interaction, absence of classroom setting, technical issues, high chances of distraction, lack of IT equipment for many students, absence of appropriate and relevant students' preparation for online education, and the lack of classroom observation (Lindzon, 2020; Keskin, and Yurdugül, 2020; Angdhiri, 2020; Sadeghi, 2019). In Lindzon's (2020) study, students' performance results were negatively affected by some of these significant deficiencies of the lockdown of their educational institutions and the lack of onsite instruction. Sadeghi (2019) compared the advantages to the disadvantages of e-learning, stating that:

The list of advantages seems to outweigh the list of disadvantages. Distance learning can be at least as effective as conventional classroom learning under certain situations; it hasn't been claimed that e-learning can replace traditional classroom learning. Like any kind of educational program, distance learning comes with a host of pros and cons. (p.85)

Wang, Zhao, and Zhang (2020) also confirmed that Chinese students were afraid to lose their academic year due to ineffective virtual learning systems. Most learners do not persist in their education activities outside their schools as they need a classroom setting and teacher monitoring; just a few tend to persist and comparatively do well. These cases indicate that educational institutions are not buildings for only delivering curricula and imparting knowledge; they instead provide students with places for socialization and zones of proximal development (Wagner, 1995) where the appropriate meanings develop and grow. As a result, students acquire 
lifestyles, communication skills, appropriate behaviors, and coursework. Bozavlı's (2021) findings revealed:

Participants still trust and believe in the school in learning foreign languages. Participants' beliefs about the school may be associated with social perception and social realities in the field of education in Turkey.... The students think that it is not possible to learn a foreign language without school and that also listening and speaking skills in a foreign language cannot be improved online. Additionally, they do not believe that distance foreign language learning is fruitful. (pp.13-14)

The crucial factors required for successful e-education include appropriate approaches and applications, technology accessibility, assessment criteria and tools, curriculum content, and course syllabus. Sadeghi (2019) argued that virtual education has positive and negative effects on both instructors and learners, like any teaching methodology. In addition to the epidemiological advantages of virtual education amid the COVID-19 pandemic, further and worth mentioning benefits include more participant comfort and convenience, ease of access to resources irrespective of time and place. Saving commuting costs and decreasing air pollution are also valuable aspects. On the other hand, virtual classes have some downsides, including high chances of distraction, difficulty staying in contact with the teacher, low-quality internet access, or limited technical skills. (Sadeghi, 2019). Furthermore, some benefits, such as educational freedom and time convenience, could at the same time be of disadvantages and critical, particularly for learners with time management, self-regulation, and focusing issues (ChooiSeong, Kah-Mun, \& Chee-Seong, 2021).

While the nature of pedagogical instructions may differ across subject areas, English language teaching was no exception in having to go online. This situation raised questions and issues of concern, such as whether or not learners would positively perceive virtual EFL instruction. The current study explores a language teaching context focusing on the attitudes and perspectives of EFL learners towards virtual and online education. Effective foreign language Education is usually an engaging communicative process that positively impacts the students (Stern, 1987). Students' perspectives towards language learning are based on their values and attitudes. Individuals have all sorts of positive or negative attitudes based on various values (Wright, 1987). After two semesters of online education with no onsite courses, the researcher investigated EFL medical students' perceptions of virtual teaching methods and learning styles.

\section{Methods}

The researcher conducted quantitative as well as qualitative methods analyses using the following data collection tools and strategies:

\section{Participants}

A total of 57 female Saudi students volunteered to participate in this study. A convenience sampling method was adopted in the data collection. "Convenience sampling involves low cost and easy accessibility" (p.370) (Chooi-Seong, Kah-Mun, \& Chee-Seong, 2021). Ben-Shlomo, Brookes, and Hickman (2013) assume that "useful results would be obtained if participants were willing and volunteered to take part in a research study" (section a1). The sample consisted of two groups of first-year medical students attending the "English for General Purposes" (EGP) 
course and "English for Specific Purposes" (ESP) during the academic year of 2020-2021 at a Saudi university. They were between 18 and 22 years old and considered of intermediate level of English language according to the results of the program placement test. The Author taught these groups in previous semesters.

Concerning their familiarity with the technology being used in their classes, respondents' skills vary as $66.1 \%$ self-reported having moderate IT skills, $30.4 \%$ have good or elevated command, and $3.6 \%$ come with limited or low skills. Concerning distance education experience, $65.5 \%$ of these students did not participate in any online education before the pandemic. On the other hand, $34.5 \%$ of them have already had previous online education experience.

\section{Research instruments}

1. A questionnaire consisting of fifteen closed-ended questions was created with a 5-Likert scale administered via Google online forms. The questionnaire is based on Bączek et al.'s (2021) questionnaire consisting of four parts: In the first part, participants were asked to describe their IT skills and state whether or not they had previously participated in any online courses. In the second part, students were given a list of advantages and challenges of online learning from which they were asked to choose what is true for them. In the third, respondents efficiently compared onsite to online classes to develop their knowledge, language skills, and social competence. Students also rated their activity in both classes using the Likert scale from 1-5 (1= highly inactive to $5=$ highly active). Finally, in the fourth part, participants rated their level of enjoyment of online education using the Likert scale from 1 to 5 ( 1 = highly unenjoyable, $5=$ highly enjoyable).

2. Researcher's notes from observation: The researcher's notes relate to the students' participation, activity, and interest in online education. They were used to justify and clarify the numerical data.

3. Documents including Umm Al-Qura university guideline for online teaching, the English Language Center weekly pacing and syllabus, samples of students' work, documented experiences of online education practice, and the researcher's (teacher) record of students' online classroom participation and activities.

\section{Procedures}

The questionnaire link of the form was distributed among participants via WhatsApp groups. After answering it, the data was analyzed using Excel. Percentages and averages were used for data analysis. In addition, the researcher's (teacher) notes were collected during virtual teaching. They were written during or right after the online classes. These notes and documents were used to explain the data and relate the numerical data to the students' activities, enjoyment, and participation.

\section{Findings}

The findings obtained from the questionnaire parts are represented in the five tables below. Table one illustrates the percentages, number of students, and the averages of students' agreement on the advantages and disadvantages of distance education. 
Arab World English Journal (AWEJ) 2nd Special Issue on Covid 19 Challenges January 2022

Attitudes and Perspectives of Saudi Female Medical Students towards Online EFL

Elashhab

Table 1. The percentages of students' accordance with the statements given on online education

\begin{tabular}{|l|l|l|l|}
\hline \multirow{4}{*}{$\begin{array}{l}\text { Advantages } \\
\text { of } \\
\text { distance } \\
\text { education }\end{array}$} & Statements & $\begin{array}{l}\text { Students' } \\
\text { agreements }\end{array}$ & $\begin{array}{l}\text { No. of Students } \\
\text { Out of 57 }\end{array}$ \\
\cline { 2 - 4 } & Education at your pace & $70.2 \%$ & 40 \\
\cline { 2 - 4 } & Capability to stay home & $66.7 \%$ & 37 \\
\cline { 2 - 4 } & Availability of recorded meetings & $86 \%$ & 48 \\
\cline { 2 - 4 } & Comfortable surrounding & $71.9 \%$ & 40 \\
\cline { 2 - 4 } & Classes interactivity & $22.8 \%$ & 13 \\
\hline \multirow{3}{*}{$\begin{array}{l}\text { Limitation } \\
\text { of }\end{array}$} & Average agreement on all advantages & $63.52 \%$ & 35.6 \\
\cline { 2 - 4 } educationce & Limited interaction with the teacher & $43.9 \%$ & 25 \\
\cline { 2 - 4 } & Technical problems & $69.5 \%$ & 39 \\
\cline { 2 - 4 } & Lack of communication with peers & $24.6 \%$ & 14 \\
\cline { 2 - 4 } & Poor education quality at home & $24.6 \%$ & 14 \\
\cline { 2 - 4 } & Loss of self-discipline & $22.8 \%$ & 13 \\
\cline { 2 - 4 } & Social isolation & $54.4 \%$ & 31 \\
\hline & Average agreement on all limitations & $39.96 \%$ & 22.66 \\
\hline
\end{tabular}

Table one demonstrates that $70.2 \%$ liked education at their own pace. It also shows that $66.7 \%$ chose to study from home and $71.9 \%$ admired being comfortable during online classes. Again table one indicates that $86 \%$ of students appreciated getting back to the recordings of virtual classes. At the same time, only $22.8 \%$ were able to interact. In general, table one demonstrates that an average $(63.52 \%)$ of students chose distance education over classroom education during virtual classes.

Concerning the limitations of distance education, many students experienced network difficulties during their online education. This issue tended to be a significant challenge as $69.5 \%$ of respondents complained about it. Social isolation was another disadvantage voiced by students $(54.4 \%)$ and came second, followed by reduced interaction with the teacher $(43.9 \%)$. Table one also indicates that $24.6 \%$ of students reported a lack of classmate interaction. Generally, table one illustrates that an average (39.96\%) of students did not prefer online education.

Table 2. Students' perspectives about the efficiency of distance education

\begin{tabular}{|l|l|l|l|l|l|}
\hline & \multicolumn{5}{|l|}{ E-education } \\
\cline { 2 - 6 } & $\begin{array}{l}\text { Highly } \\
\text { inefficient }\end{array}$ & Inefficient & Neutral & Efficient & $\begin{array}{l}\text { Highly } \\
\text { efficient }\end{array}$ \\
\hline Increasing Knowledge & $1.8 \%$ & $14 \%$ & $50.9 \%$ & $19.3 \%$ & $14 \%$ \\
\hline $\begin{array}{l}\text { Improving language } \\
\text { skills }\end{array}$ & $1.8 \%$ & $15.8 \%$ & $35.1 \%$ & $33.3 \%$ & $14 \%$ \\
\hline $\begin{array}{l}\text { Improving social } \\
\text { competence }\end{array}$ & $22.8 \%$ & $15.8 \%$ & $36.8 \%$ & $15.8 \%$ & $8.8 \%$ \\
\hline Average & $8.8 \%$ & $15.2 \%$ & $40.9 \%$ & $22.8 \%$ & $12.3 \%$ \\
\hline
\end{tabular}

Table two illustrates students' perspectives towards distance education efficiency for knowledge expansion, language skills development, and social competence improvement. Only $1.8 \%$ of respondents reported that distance education is highly inefficient for knowledge expansion and language skills development. However, $22.8 \%$ of them perceived distance 
education as highly inefficient for improving social competence. In addition, 14\% saw distance education as inefficient for knowledge expansion, and $15.8 \%$ felt that distance education is inefficient for improving their language skills and social competence. In contrast, table two shows that $19.3 \%$ considered distance education an efficient medium for knowledge expansion, while $14 \%$ thought it is highly efficient for knowledge development.

On students' perceptions concerning improving language skills, 33.3\% reported distance education as efficient. Again $14 \%$ saw distance education as highly efficient for improving language skills. Whereas only $15.8 \%$ reported that distance education is efficient, and $8.8 \%$ said it is highly efficient for improving social competence. On average, $22.8 \%$ and $12.3 \%$ have positive attitudes towards distance education versus $8.8 \%$ and $15.2 \%$ who have negative perspectives towards it, and $40.9 \%$ chose to be neutral.

Table 3. Students' perspectives about the efficiency of onsite education

\begin{tabular}{|l|l|l|l|l|l|}
\hline \multirow{2}{*}{} & \multicolumn{4}{|l|}{ Face-to-Face Education } \\
\cline { 2 - 6 } & $\begin{array}{l}\text { Highly } \\
\text { inefficient }\end{array}$ & Inefficient & Neutral & Efficient & $\begin{array}{l}\text { Highly } \\
\text { efficient }\end{array}$ \\
\hline Increasing Knowledge & $7 \%$ & $10.5 \%$ & $19.3 \%$ & $28.1 \%$ & $35.1 \%$ \\
\hline Improving language skills & $3.5 \%$ & $21.1 \%$ & $29.8 \%$ & $22.8 \%$ & $22.8 \%$ \\
\hline Improving social competence & $3.5 \%$ & $3.5 \%$ & $22.8 \%$ & $36.8 \%$ & $33.3 \%$ \\
\hline Average & $4.6 \%$ & $11.5 \%$ & $23.8 \%$ & $29.2 \%$ & $30.4 \%$ \\
\hline
\end{tabular}

Table three depicts students' perspectives about the efficiency of onsite education, reflecting learners' negative attitudes towards classroom instruction in terms of expanding knowledge; only $7 \%$ felt that it is highly inefficient, and $10.5 \%$ reported its inadequacy for knowledge development. 3.5\% reported that onsite education is highly inefficient for improving language skills and social competence. At the same time, $21.1 \%$ saw it inadequate to improve language skills. Only 3.5 perceived it as inefficient for improving social competence, and an average of $23.8 \%$ of the respondents tended to have a neutral position towards this aspect.

About students' positive perspectives towards onsite education, the data in table three show that $28.1 \%$ of students reported face-to-face education efficiently expands education and knowledge, and $35.1 \%$ viewed it as highly efficient. Concerning improving language skills, $22.8 \%$ felt that onsite education is efficient, and an equal percentage (22.8) viewed it as highly efficient. On improving social competence, $36.8 \%$ stated that onsite education is efficient, and $33.3 \%$ thought it is highly efficient. Substantially, on average, $29.2 \%$ and $30.4 \%$ preferred faceto-face education versus only $4.6 \%$ (perceived it as highly inefficient) and $11.5 \%$ (felt it is inefficient) who had negative attitudes towards onsite education, in addition to $23.8 \%$ who stood neutrally.

Table 4. Learners' participation during virtual classes compared to onsite classes

\begin{tabular}{|l|l|l|l|l|l|}
\hline & highly inactive & Inactive & Neutral & Active & highly active \\
\hline Face-to-Face education & $5.3 \%$ & $12.3 \%$ & $26.3 \%$ & $14 \%$ & $42.1 \%$ \\
\hline E-education & $1.8 \%$ & $10.5 \%$ & $36.8 \%$ & $36.8 \%$ & $14 \%$ \\
\hline
\end{tabular}

Table four compares learners' activeness and engagement during both virtual and onsite classes. $36.8 \%$ of respondents tend to have a neutral position towards online education, and 
Arab World English Journal (AWEJ) 2nd Special Issue on Covid 19 Challenges January 2022

Attitudes and Perspectives of Saudi Female Medical Students towards Online EFL

Elashhab

$22.8 \%$ have a neutral attitude towards onsite education. The data show that $42.1 \%$ of students felt highly active and involved during onsite classes, while $14 \%$ reported being highly active during virtual classes.

Table 5. Learners' enjoyment of virtual classes during the COVID-19 pandemic

\begin{tabular}{|l|c|c|l|l|l|}
\hline & highly unenjoyable & unenjoyable & Neutral & enjoyable & highly enjoyable \\
\hline E-education & $3.5 \%$ & $15.8 \%$ & $35.1 \%$ & $26.3 \%$ & $19.3 \%$ \\
\hline
\end{tabular}

Table five illustrates learners' enjoyment in virtual courses during the COVID-19 pandemic. Again, $35.1 \%$ of participants have a neutral attitude. On the other hand, $26.3 \%$ and $19.3 \%$ of participants enjoyed and significantly enjoyed virtual classes, respectively. In contrast, only $3.5 \%$ and $15.8 \%$ of students did not enjoy online education during COVID-19.

\section{Discussion}

Online education is distance education using various devices to deliver information virtually. In this respect, productive distance education requires instructors and learners to be adapted to and qualified to use those devices for education. In this section, the researcher discusses the needs of students for the efficient use of educational platforms. "COVID-19 pandemic imposed challenges on both teachers and students," language education institutions have approved online or virtual courses to comply with health and safety measures. However, as it has been a new tendency in language education, students' perceptions of online education vary. Each learner is eager to learn "English as a foreign language," but not all of them "have adopted to the online orientation of English language education." Instead, they hold various concerns about the approach, such as the actual presence of the instructor, student interaction and participation, social communication, expanding knowledge, and developing language skills. In their study, Garcia, Weiss, and Engdahl (2020) argue that before COVID-19, pandemic learners consumed ample time online. That time was spent "socializing with friends, playing games," browsing the web, navigating social media for news and information, or checking emails.

\section{How do virtual education methods influence students' moods and education behavior?}

Even with the pandemic and changing circumstances, it is found that learners tend to spend less time doing school-related activities than the time that they spend on online entertainment and social media (Elashhab, 2020). The arguments of Garcia et al. (2020) and Elashhab (2020) also suggest that as learners suddenly shifted to online education over the past months, they did so without having any fair practice or experience in online education. However, this transformation obliged learners to shift their gadgets-usage habits from playing and entertainment to serious education.

In this study, when learners were asked about their e-education skills, it was found that, on average, $29.8 \%$ were highly skilled using online communication platforms such as Blackboard, WebEx, Zoom, and Microsoft Team. Whereas $66.7 \%$ had moderate skills, and $3.5 \%$ had limited IT skills of using e-education platforms such are used for sharing digital content, uploading homework, and other materials. Thus, for $35.7 \%$ of the students, the online educational experience was not new, unlike others (64.3\%) who were exposed to such forms of education for the first time. On the variation of students' technical skills, Bettinger and Loeb (2017), and Chooi-Seong, Kah-Mun, and Chee-Seong, (2021). highlighted a critical aspect that online 
Arab World English Journal (AWEJ) 2nd Special Issue on Covid 19 Challenges January 2022

Attitudes and Perspectives of Saudi Female Medical Students towards Online EFL

Elashhab

courses are challenging, especially for the least prepared students. Nenko et al. (2020) supported this finding by calling for intensive preparation for any future waves "to ensure that learners are equipped with the required skills" for utilizing those online applications and platforms.

\section{Advantages and Limitations of Distance Education}

2- What are the students' perspectives towards virtual education amid the COVID-19 pandemic?

Concerning the advantages of e-education from the respondents' point of view, table one demonstrates that $70.2 \%$ liked education at their own pace. These results coincide with Li and Lalani's (2020) statement that e-education saved up to $60 \%$ of the time needed for a conventional classroom setting as learners could learn at their own pace. They can go back and forth rereading, re-assessing, passing and skipping, or speeding up through topics and ideas as they prefer. Table one also shows that $66.7 \%$ chose to study from home and $71.9 \%$ admired being comfortable during online classes. Garcia et al. (2020) confirm that education styles significantly vary because students have various innate personal characteristics. Their education and knowledge growth are formed by numerous details and considerations, in and out of classrooms. Again table one indicates that $86 \%$ of students appreciated getting back to the recordings of virtual classes. At the same time, only $22.8 \%$ could interact during virtual classes. Concerning the limitations of distance education, the results shown in table one are consistent with Li and Lalani's (2020) assumption that some students who experience the absence of reliable internet access or lack technology devices such as laptops and microphones struggle to participate in online education. Ali (2020) also reported that students from rural and isolated areas had issues with poor Internet connectivity or even a lack of electrical power from time to time.

In general, table one demonstrates that an average $(63.52 \%)$ of students chose distance education over classroom education because of the listed advantages in table one. These eeducation benefits are similar to what Yulia et al. (2019) found in their study. Using online education, students did not need to spend money and time commuting as they would not travel to schools as they could have their courses in any place at their convenient times. On the same line, Alshehri and Cumming (2020) reported that students and teachers presumed that mobile phone technologies improved scholarly communication by asking questions and seeking clarification of complex points. This result of $63.52 \%$ is higher than the Amir et al. (2020) study comparing online with conventional education methods, which reported a lower preference (44.2\%) for online education than conventional classroom education. Thus, in the present study, students' perspectives and perceptions towards e-education are more favorable. In the current study, education is fully delivered online. However, Alshehri, Rutter, and Smith (2019); Sadeghi (2019); Bączek et al. (2021) suggest that the whole online educational process gives a sense of impracticality or unreality. Moreover, it dramatically relies on the student's commitment to the course.

Regarding the limitations of distance education, many students experienced network difficulties during their online education. This issue tended to be a significant challenge as $69.5 \%$ of respondents complained about it. It is worth mentioning that the internet connection was the central issue for the learners and the teachers that troubled them during their online education. Online classes were occasionally canceled due to the communication difficulties between instructors and students due to the heavy load and overuse of the internet, especially during the 
morning as all students around the country study online. Social isolation was another disadvantage voiced by students (54.4\%) and came second, followed by reduced interaction with the teacher (43.9\%). Angdhiri (2020) claims several problems usually appear in an online educational setting, including slow internet connection. Table one also indicates that $24.6 \%$ of students reported a lack of classmate interaction. This finding coincides with Mulyani et al.'s (2021) findings that online educational approaches generated gaps between instructors and students in terms of communication. They also modified how instructors provide feedback, motivate, and interact with students.

On another concern, $24.6 \%$ of the respondents reported having poor educational conditions at home, such as young siblings' noise and family visits, and $22.8 \%$ admitted lack of selfdiscipline. Amir et al. (2020) and Chooi-Seong, Kah-Mun, \& Chee-Seong, (2021). supported this finding. Their studies assert that studying from home usually needs greater motivation and selfdiscipline to pursue online courses, especially during the first period when students are not familiar with the new online educational system. These assertions could lead to increased study obligations. In addition, many students found that the "workload of online classes is larger than that of onsite classes" (Angdhiri, 2020). Further, concerning the practical aspects of the EFL education environment, students found it "less appealing and engaging due to its limitations" (Ali, 2020; Angdhiri, 2020; Abbasi et al., 2020). These findings are also in agreement with other studies on students' attitudes and perceptions in many other countries like China (Zhao et al., 2020), Malaysia (Ali, 2020), Indonesia (Mulyani et al., 2021; Angdhiri, 2020). For example, in Pakistan, Abbasi et al. (2020) showed that $77 \%$ of Pakistani students negatively perceived eeducation. Moreover, Mulyani et al. (2021) found that 55.8\% of Indonesian students had negative perceptions.

Despite all the students' agreements on the limitations of virtual education during the pandemic, table one demonstrates a lower average (44.46\%) of students who chose onsite education over online education. Per contra, a higher average $(63.52 \%)$ of learners chose distance education over onsite education. This study agrees with Keskin and Yurdugül's (2020) findings demonstrating their students' preference of distance education over classroom education. However, this study's results differ from Amir et al.'s (2020) results in which only $44.2 \%$ of students chose online education over onsite education. Keskin and Yurdugül's (2020) study revealed "a correlation between the preference for education delivery and the constructs of selfcompetence, online education motivation, and task value." They reveal that "students with high task values, online education motivation, and self-efficacy" chose distance educational environments.

\section{Effectiveness of Distance Education Compared to Onsite Education}

On students' perceptions concerning improving language skills, $33.3 \%$ reported distance education as efficient. Again 14\% saw distance education as highly efficient for improving language skills. Whereas only $15.8 \%$ reported that distance education is efficient, and $8.8 \%$ said it is highly efficient for improving social competence. On average, $22.8 \%$ and $12.3 \%$ have positive attitudes towards distance education versus $8.8 \%$ and $15.2 \%$ who have negative perspectives towards it, and $40.9 \%$ chose to be neutral. Li and Lalani (2020) explained that those with adequate technology tend to favor online education over onsite education. Their study found evidence that online education can be more efficient in several ways, such as retaining more 
information and requiring "less time to learn, as students learn at their own pace." Their research shows that, on average, students recalled up to $60 \%$ more information after their online education compared to only $8-10 \%$ after their onsite education. These findings are mainly due to the learners' ability to learn faster and better online (Alshehri et al., 2019; Li and Lalani, 2020).

Findings in table three, in particular, could be related to the limitation in the technology used by students, as they tend to favor Mobile phones among other devices (tablets or computers) for online education. Alshehri \& Cumming (2020) and Al-Nofaie (2020) also reported students' preference for mobile phones over other gadgets. In the present study, $85 \%$ of the students use mobile phones, while $15 \%$ use laptops or tablets. Confirming this tendency among students, Abbasi et al. (2020) also reported that $76 \%$ of their students use mobile phones for their eeducation.

\section{Learners' participation, Activeness and Enjoyment during Virtual Classes 3-Does distance education affect EFL learners' class participation?}

Many students technically struggle to participate in online education as they lack reliable devices or internet access. This issue is noticed in studies across many countries (Ali, 2020; Angdhiri, 2020; Abbasi, Ayoob, Malik, \& Memon, 2020). Further, Al-Nofaie (2020) reports that some "students did not have headphones during online classes," which hindered their communication with their teachers and peers. In the context of this study, the University of Umm AL-Qura provides students in need with digital equipment such as tablets and laptops. Many students, however, felt shy to admit that they were in need and refused to apply for the available equipment and depended on their limited capacity mobile phones. This position could justify students' reduced interaction with their teacher and classmates during virtual classes, which consequently seemed to have caused their negative perspectives towards distance education. The present study also shows that $36.8 \%$ viewed themselves as more involved in online classes versus only $14 \%$ who said they were more involved in onsite classes. According to Aristovnik et al. (2020), it is assumed that involved students in virtual classes had conformed reasonably well to the new educational experience.

Further, $17.6 \%$ of students reported being inactive in face-to-face classes, while $12.3 \%$ were not involved in online classes. One explanation for students' disengagement in onsite classes could relate to their shyness to speak English in front of their peers in onsite classes. This result is congruent with the work of "Dr. Amjad, a Professor at The University of Jordan," who used Lark as a medium of instruction. He noticed that his students found it easier to communicate online than in onsite classes (cited in Abbasi, Ayoob, Malik, \& Memon, 2020).

In contrast, students may retain a negative attitude towards the online educational approach as online teaching could overburden learners with extra studying materials and assignments. Amir et al.'s (2020) work shed light on this, explaining that students compare their workload before and after canceling classes. They find it more challenging to concentrate during online education than in regular classrooms. The work also reports students' disclosure of lower study achievement since the cancellation of the onsite education. It is also apparent that distance education demands students to disregard the electronic amusements and distractions before them day and night and solely focus on their education. 
Furthermore, weak internet connectivity also contributes to the challenges in doing assignments given by instructors. Students were anxious about the grades that they would get (Mulyani et al., 2021). As shown in the results above, 43.9\% of the EFL university students showed negative perceptions of the implementation of e-education during the pandemic. However, compared to onsite, e-education was perceived to impact language skills development and social competence, as it limited student-teacher interaction. This finding is consistent with work (Angdhiri, 2020) "presented in Singapore, in which 86\% of the participants highlighted that e-teaching methodology limits student-teacher interaction." Furthermore, more than half $(59.6 \%)$ of the participants in the present study approved that they like onsite education because it expands knowledge, social competence, and language skills. In the same vein, Layali and AlShlowiy (2020) and Sadeghi (2019) concluded that many students experienced obstacles to integrating mobile technologies, such as slow Internet connectivity, and asked for institutional support to solve such problems.

\section{4-To what extent was online education enjoyable to language learners?}

Online EFL education is entirely different from onsite education. It is divergent concerning enjoying the classroom environment. Data shows learners' enjoyment in virtual courses during the COVID-19 pandemic. The most considerable portion (35.1\%) of participants have a neutral attitude. On the other hand, $26.3 \%$ and $19.3 \%$ enjoyed and significantly enjoyed virtual classes, respectively.

In contrast, only $3.5 \%$ and $15.8 \%$ of students did not enjoy online education during COVID-19. These findings are similar to Bączek et al.'s (2021) findings as both studies have higher percentages of participants who rated e-learning as enjoyable. Bączek et al. (2021) studied medical students' acceptance of e-learning in Poland. They found that $73 \%$ of their participants enjoyed e-learning, and 15\% of them felt it was highly enjoyable versus $17 \%$ of their students did not enjoy it, and $10 \%$ found it highly unenjoyable. All the issues mentioned above and challenges could negatively affect the students' enjoyment of online learning. The present study findings also agree with Alshehri et al.'s (2019); Li and Lalani's (2020) findings that students learn faster and better online when they accept virtual learning and enjoy it.

\section{Conclusion}

Distance education processes were ambiguous to the students. Most of them were not appropriately trained in using the electronic platforms and applications, so they had several explicit issues and concerns such as uploading homework and other materials, opening online timed exams, and submitting assignments in the correct electronic places. Consequently, these issues have changed students' attitudes and perspectives towards virtual education. An average of $44.46 \%$ of students chose onsite learning during the lockdown situation over distance education because of the technical and connectivity challenges. Surprisingly, however, this study presented evidence that despite these challenges, an average of $63.52 \%$ of students liked distance education, as they have comfortable surroundings stay home, and have access to recorded lessons. These findings showed an interesting result of high percentages of Saudi female medical students who expressed their enjoyment, acceptance, and a positive attitude towards e-education of English language instruction during the COVID-19 pandemic despite all the technical difficulties they experienced. This result reveals that both learners and instructors generally encountered some technical issues, which caused class cancellation. Therefore, learners would 
not miss any classes. Instead, they considered it an advantage that would reduce the course materials. The present study demonstrates essential findings for improving and developing online educational means and approaches in the future. The data in this study and the highlights of students' perspectives may allow for a more holistic picture of the different aspects of eeducation. Data on students' perceptions towards online EFL teaching and face-to-face education collected through various instruments would provide feedback to teachers and help increase their understanding of online EFL instruction in similar contexts. It could also contribute to improving online education incomparable educational environments.

\section{About the Author:}

Seham Elashhab is an assistant professor at English Language Centre, Umm ALQura University. She holds a Ph.D. in Applied Linguistics from the University of Ottawa, Canada. She has more than 27 years of English teaching experience. She has published research papers on language teaching and learning and teacher development and training in various journals, and she has conducted workshops at several conferences worldwide. Seham is a member of the Accreditation Committee, Recruitment Committee, and the Professional Development Unit. ORCID: https://orcid.org/0000-0003-3157-3066

\section{References}

Abbasi, S., Ayoob, T., Malik, A., \& Memon, S. (2020). Perceptions of students regarding Eeducation during COVID-19 at a private medical college. Pakistan Journal of Medical Sciences, 36, (COVID19-S4) 57-61. https://doi.org/10.12669/pjms.36.COVID19$\underline{\mathrm{S} 4.2766}$

Ali, W. (2020). Online and Remote Education in Higher Education Institutes: A Necessity in light of COVID-19 pandemic. Higher Education Studies, 10, 16-25. DOI:10.5539/hes.v10n3p16

Allo, M. (2020). Is the online education good in the midst of the COVID-19 pandemic? The case of EFL learners. Journal Sinestesia, 10(1), 1-10. Available at: https://sinestesia.pustaka.my.id/journal/article/view/24

Al-Nofaie, H. (2020). Saudi University Students' Perceptions towards Virtual Education During Covid-19 Pandemic: A Case Study of Language Learning via Blackboard. Arab World English Journal, 11(3) 4-20.

DOI: https://dx.doi.org/10.24093/awej/vol11no3.1

Alshehri, A., \& Cumming, T. (2020). Mobile technologies and knowledge management in higher education institutions: Students' and educators' perspectives. World Journal of Education, 10(1), 12-22. DOI: $10.5430 /$ wje.v10n1p12

Alshehri, A., Rutter, M., \& Smith, S. (2019). Assessing the relative importance of an elearning system's usability design characteristics based on students' preferences. European Journal of Educational Research, 8(3), 839-855. https://doi.org/10.12973/eu-jer.8.3.839

Amir, L., et al. (2020). Student Perspective of classroom and Distance Education during COVID-19 Pandemic in the Undergraduate dental study program Universitas Indonesia. BMC Medical Education, 20(1), 1-8. https://doi.org/10.1186/s12909-02002312-0 
Arab World English Journal (AWEJ) 2nd Special Issue on Covid 19 Challenges January 2022

Angdhiri, R. P. (2020). Challenges of home education during a pandemic through the eyes of a student. Jakarta Post. Available at: https://www.thejakartapost.com/life/2020/04/11/challenges-of-home-educationduringa-pandemic-through-the-eyes-of-a-student.html

Aristovnik, A., Kerži čc, D., Ravšelj, D., Tomaževi`c, N., \& Umek, L. (2020). Impacts of the COVID-19 Pandemic on Life of Higher Education Students: A Global Perspective. Sustainability, 12(20), 1-34. https://doi.org/10.3390/su12208438

Bączek, M., et al. (2021). Students' perception of online education during the COVID-19 pandemic: A survey study of Polish medical students. Medicine, 100(7), e24821. https://doi.org/10.1097/MD.0000000000024821

Ben-Shlomo Y, Brookes S, \& Hickman M. (2013). Lecture Notes: Epidemiology, Evidencebased Medicine and Public Health (6th ed.), Wiley-Blackwell, Oxford. Available at: https://www.healthknowledge.org.uk/public-health-textbook/research-methods/1aepidemiology/methods-of-sampling-population

Bettinger, E., \& Loeb, S. (2017). Promises and Pitfalls of Online Education. Evidence Speaks Reports, (2), 1-4. Available at: https://www.brookings.edu/research/promises-andpitfalls-of-online-education/

Bozavll, E. (2021). Is Foreign Language Teaching Possible Without School? Distance Learning Experiences of Foreign Language Students at Ataturk University During the Covid-19 Pandemic. Arab World English Journal, 12(1) 3-18._ DOI: https://dx.doi.org/10.24093/awej/vol12no1.1

Chooi-Seong L., Kah-Mun A., \& Chee-Seong L. (2021). Beyond Conventional Classroom Learning: Linking Emotions and Self-Efficacy to Academic Achievement and Satisfaction with Online Learning during COVID-19 Pandemic. Journal of Education and e-Learning Research, 8(4), 367-374.

Available

at: https://www.researchgate.net/publication/356102973_Beyond_Conventional_Classroo m_Learning_Linking_Emotions_and_Self-

Efficacy_to_Academic_Achievement_and_Satisfaction_with_Online_Learning_during the_COVID-19_Pandemic

Elashhab, S. (2020). A Study on Arabic Speaking Students' Attitudes towards Group Work in the EFL Classroom. The Asian ESP Journal, 16(4), 303-312. Available at: https://www.asian-esp-journal.com/volume-16-issue-4-july-2020/

Garcia, E., Weiss, E., \& Engdahl, L. (2020) Access to online learning amid coronavirus is far from universal, and children who are poor suffer from a digital divide. Economic Policy Institute. Available at: https://www.epi.org/blog/access-to-online-learning-amidcoronavirus-and-digital-divide/

Keskin, S., \& Yurdugül, H. (2020). Factors Affecting Students' Preferences for Online and Blended Education: Motivational Vs. Cognitive European Journal of Open, Distance and E-Education, 22(2), 72-86. https://doi.org/10.2478/eurodl-2019-0011

Layali, K., \& Al-Shlowiy, A. (2020). Students' perceptions of e-education for ESL/EFL in Saudi universities at the time of coronavirus: A literature review. Indonesian EFL Journal, 6(2), 97-108.

DOI: $10.25134 /$ ieflj.v6i2.337 
Arab World English Journal (AWEJ) 2nd Special Issue on Covid 19 Challenges January 2022

Li, C., \& Lalani, F. (2020). The COVID-19 pandemic has changed education forever; This is how. World Economic Forum. Available at: https://www.weforum.org/agenda/ 2020/04/coronavirus-education-global-covid19-online-digital-education/

Lindzon, J. (2020). School closures are starting, and they will have far-reaching economic impacts. Fast Company. Available at: https://www.fastcompany.com/90476445/schoolclosures-are-starting-and-theyll-have-far-reaching-economic-impacts

Mulyani, M., Fidyati, F., Suryani, S., Suri, M., \& Halima tussakdiah, H. (2021). University students' perceptions through e-education implementation during COVID-19 Pandemic: Positive or negative features dominate? Studies in English Language and Education, 8(1), 197-211. https://doi.org/10.24815/siele.v8i1.17628

Nenko, Y., Kybalna, N., \& Snisarenko, Y. (2020). The COVID-19 Distance Education: Insight from Ukrainian Students. Revista Brasileira de Educação do Campo, 5, 1-19. http://doi.org/10.20873/uft.rbec.e8925

Sadeghi, M. (2019). A Shift from Classroom to Distance Education: Advantages and Limitations. International Journal Research in English Education, 4(1), 80-88. Doi: 10.29252/ijree.4.1.80 I

Stern, H. H. (1987). Fundamental concepts of language teaching. Oxford University Press.

Wagner, T. (1995). What's School Really for, Anyway? And Who Should Decide? The Phi Delta Kappan, 76(5), 393-398. Available at: https://www.jstor.org/stable/20405349

Wang., C., Zhao, H., \& Zhang, H. (2020). Chinese college students have higher anxiety in new semester of online learning during COVID-19: A machine learning approach. Frontiers in Psychology, 11, 3465. https://doi.org/10.3389/fpsyg.2020.587413.

Wright, T. (1987). Roles of teachers and learners. Oxford University Press.

Yulia, A., Husin, N. A., \& Anuar, F. I. (2019). Channeling assessments in English language education via interactive online platforms. Studies in English Language and Education, 6(2), 228-238. DOI: $10.24815 /$ siele.v6i2.14103

Zhao, L. X., et al. (2020). Comparing face-to-face and online teaching of written and spoken Chinese to adult learners: An Edinburgh-Sheffield case study. International Journal of Chinese Language Teaching, (1), 83-98.

DOI: $10.46451 /$ ijclt.2020.06.05. 